\title{
KREASI IKAT ENDEK SEBAGAI PRODUK PENUNJANG PARIWISATA BALI
}

\author{
I Gusti Ayu Melistyari Dewi \\ Universitas Udayana \\ Email: melistyari.dewi@gmail.com \\ I Wayan Ardika \\ Universitas Udayana \\ Email: ardika52@yahoo.co.id \\ I Nyoman Sunarta \\ Universitas Udayana \\ Email: cairns54@yahoo.com
}

\begin{abstract}
As a tourism destination in the world, Bali attracts many tourists to visit because of its tourist attractions and culture. One form of Balinese cultural products is Balinese endek, a traditional Balinese fabric comes in a myriad of beautiful colors and geometrical designs. The experience of weaving Balinese Endek is the phenomenon of commodification in its essence as a creative industry. The author uses this paper to be able to critically examine the Balinese Endek function with a culture studies approach in relation to the use of endek in the tourism sector. The instrument for analyzing this paper is using the commodification theory, which is explaining about something that is not related to the production process into a product that is consumed in bulk, yet is related to how a product is marketed to the target market in order to meet consumer needs. The methodology used in examining the phenomenon of the commodification of Balinese endek is a critical method that is emancipatory in nature, namely the involvement of producers or weavers and business people (who are involved in the tourism industry). The results of this paper are: (1) The symbolic meaning that is typical of Balinese Endek is an attraction and has the potential to attract tourists, thus helping to improve the economy of the Balinese people. (2) The dynamics of Balinese Endek marketing in the market are in demand by the local market as well as the global market as a creative product. (3) The development of function of the Balinese endek not solely by the local community, but also by tourists to be used as a souvenir.
\end{abstract}

Keywords: Commodification, Tenun Ikat Endek Bali, Bali Tourism 


\section{Pendahuluan}

Daya Tarik Bali sebagai daerah pariwisata di Indonesia menuntut Bali agar memberikan suatu inovasi dalam menjaga eksistensi sebagai pariwisata budaya. Hal ini ditunjang dengan penyediaan berbagai macam produk industri kreatif. Untuk meningkatkan kunjungan wisatawan tentunya diperlukan ciri khas dari tempat pariwisata yang membuatnya berbeda dari pada yang lainnya. Salah satunya dengan mengembangkan berbagai macam souvenir yang bisa menunjukan identitas dari tempat pariwisata.

Souvenir Benda yang unik dan memiliki nilai tertentu karena memuat pengalaman tertentu, diproduksi secara komersil dan dikaitkan dengan pariwisata. (Prakosa \& Cheon, 2013). Jenis-jenis souvenir khas Bali yang terkenal dan banyak diminati wisatawan adalah Jogger, Bali Home SPA, Batik Bali, Manik-manik Bali, Perak Celuk Bali, dan Tas Bali. Salah satu cindera mata atau kerajinan khas Bali yang cenderung terlupakan untuk dijadikaan souvenir adalah Kain Endek Bali.

Menurut denpsarkota.go (2017) endek merupakan kain turun temurun dari leluhur Bali yang diperkirakan dimulai sejak zaman pemerintahan Dalam Waturenggong di Gelgel Klungkung. Menurut Dewi (2013) kerajinan tenun endek dibagi menjadi tiga perode waktu yaitu perode I tahun 1985-1995, periode II tahun 1996-2006, dan periode III tahun 2007. Dewi (2013) juga mempertegas bahwa pada tahun 2008 perkembangan tenun Endek mengalami penurunan yang sangat sigifikan diakibatkan karena bahan baku, harga dan kualitas tidak sesuai dengan standar produksi. Oleh karenanya pemerintah daerah berupaya untuk mengangkat kembali industri kreatif masyarakat Bali ini dengan mewajibkan para PNS untuk mengenakan baju berbahan Endek setiap minggunya.

Kebutuhan akan kerajinan tenun endek saat ini tidak hanya diproduksi dalam bentuk kain atau wastra atau pakaian, tetapi endek juga diaplikasikan di benda-benda lain agar bertambah nilai seni dan keindahannya seperti dompet dan 
tas. Corak khas endek pun kini mulai berkembang dengan tetap memperhatikan keaslian motif endek dari Bali. Motif menjadikan perkembangan endek menjadi signifikan dan mengikuti kebutuhan pasar. Hal inilah yang perlu dikembangkan di Bali untuk meningkatkan kembali potensi kain Endek agar dikenal sampai ke Mancanegara. Secara langsung akan berdampak kepada tingkat perekonomian pengerajin dan menunjang pembangunan pariwisata ke depan.

Berdasarkan hasil observasi awal, minat akan kerajinan endek masih didominasi oleh wisatawan domestic, sedangkan wisatawan mancanegara, khususnya Jepang yang memiliki minat yang relatif tinggi terhadap kerajinan endek. Perbedaan juga ditemukan dari kecenderungan kedua jenis wisatawan tersebut dalam meminati produk endek. Wisatawan domestic cenderung lebih menyukai kerajinan endek dalam bentuk yang sudah diaplikasikan ke dalam bentuk prpoduk kreatif siap pakai seperti pakaian jadi, tas, dompet maupun sandal. Sedangkan wisatawan mancanegara cenderung lebih menyukai kerajinan endek dalam bantuk kain lembaran. Tetapi ironisnya gencarnya strategi pengembangan tenun endek yang dilakukan oleh Pemerintah Daerah tidak serta merta membuat endek menjadi produk pariwisata kreatif namun sebaliknya wisatawan lebih mengenal batik dari pada tenun endek. Oleh karenanya diperlukan suatu strategi yang dapat memperkenalkan endek lebih luas lagi dan dapat menjadi salah satu kerajinan yang diminati oleh wisatawan yakni dengan mengembangkan endek sebagai produk industry kreatif penunjang pariwisata.

Souvenir atau cendramata memiliki fungsi dalam menunjang kepariwisataan, diantaranya dalam mempromosikan daya tarik wisata dan memberikan kenangan bagi wisatawan yang berkunjung. Hal ini secara langsung akan berdampak kepada tingkat kunjungan wisatawan. Pengembangan pariwisata seperti ini akan mengakibatkan terjadinya keberlanjutan pariwisata pada satu kawasan sehingga ekonomi, social budaya dan lingkungan pun akan terjamin keberadaannya. 
Berdasarkan pemaparan di atas, adapun tujuan penelitian ini adalah untuk mengidentifikasi potensi tenun ikat Endek sebagai produk kreatif di industry pariwisata. Manfaat dari penelitian ini adalah untuk memperkaya wawasan mengenai komodifikasi Tenun Ikat Endek Bali serta pengaplikasian produk kreatif sebagai penunjang industry pariwisata. Selain itu untuk dapat memberikan pemikiran baru di industri pariwisata kreatif Bali.

\section{Landasan Teori dan Konsep}

\section{Teori Komodifikasi}

Komodifikasi diartikan sebagai proses merubah barang atau layanan yang sebelumnya menjadi subyek yang mengikuti aturan sosial non-pasar menjadi suatu subyek yang mengikuti pasar (Gleick, 2002. Dalam Kruha, 2011). Menurut Irianto (2016) komodifikasi merupakan gambaran tentang proses barang dan jasa produksi dengan cepat sebagai komoditas untuk kebutahan pasar. Irianto (2016) mengungkakan bahwa komodifikasi budaya kian marak berkembang, diakibatkan munculnya industri pariwisata. Hal ini dipertegas kembali oleh Muktiyo (2015) yang mengatakan bahwa proses komodifikasi budaya terjadi karena aksentuasi kapitalisme di dalam industry media sehingga pemahaman dan konstruksi budaya di arahkan kepada kepentingan bisnis. Komodifikasi memiliki efek sosio-ekonomi saat komodifikasi mampu mendatangkan pendapatan serta mempertahankan sebuah komunitas dengan melestarikan budayanya yang digunakan untuk mendatangkan pendapatan (Richards, 1996. Silverman, 1999. Dalam Maccarrone-Eaglen. 2009). Ditambahkan oleh Annemi (2012) yang meneliti komodifikasi yang terjadi di Afrika Selatan, yang menyatakan kalau komodifikasi yang dilakukan terhadap budaya dan warisan budaya untuk konsumsi pariwisata adalah merupakan sarana untuk meningkatkan ekonomi daerah setempat, terutama daerah pinggiran. Komodifikasi bisa ditunjukan untuk kepentingan pelestarian 
budaya sebagai tanggung jawab sosial dengan menekankan pada kekuatan masyarakat dan rasa kepemilikannya, sekaligus untuk kepentingan keuntungan ekonomi (Maccarrone-Eaglen. 2009). Ditambahkan Pröschel (2012) proses komodifikasi sangat pas dikatakan dapat menghubungkan aspek tradisi, keaslian, dan artistik dengan ciri-ciri produksi modern. Lebih lanjut Pröschel menyatakan proses komodifikasi umumnya diartikan positif sepanjang berada di tingkat yang tepat, dimana tujuan tingkat keuntungan ekonomi tidak menjadi liar yang dapat menghilangkan keaslian produk. Disamping itu komodifikasi menjadi sangat penting karena bisa menambah perkembangan identitas masyarakat serta sekaligus membantu menghidupkan kebudayaan itu sendiri.

Beberapa penelitian terkait dengan tulisan ini adalah oleh Nugraha (2012) dalam tesisnya yang bejudul "Implementasi Sightseeing Denpasar Sebagai Program Pengembangan pariwisata kota Denpasar" yang menghasilkan saran untuk pengembangan program Denpasar sightseeing yaitu: 1) Melestarikan warisan budaya Denpasar secara khusus dan budaya Bali secara umum, 2) Meningkatkan jumlah kunjungan wisatawan secara keseluruhan, 3) Membangkitkan nilai ekonomi budaya Bali. Penelitian Nugraha (2012) memiliki kesamaan dengan penelitian yakni dalam bahasan poin upaya pengembangan suatu destinasi wisata dengan memanfaatkan produk budaya sedangkan perbedaannya terletak pada subjek yang diteliti.

Judul penelitian yang lain adalah "Komodifikasi Makna Tenun Grinsing sebagai Soft Power Menghadapi Budaya Global" merupakan tulisan Londra (2016) dalam Jurnal Kajian Bali Vol. 06. Penelitian ini membahas mengenai perkembangan industri pariwisata mengakibatkan komodifikasi pada makna tenun gringsing. Melalui sentuhan kreatif, sehingga tercipta produk baru dengan makna baru. Persamaan yang ada dalam penelitian Londra (2016) dengan penelitian ini adalah penggunaan teori komodifikasi pada tenun ikat karena adanya sentuhan dunia pariwisata. Sedangkan perbedaan pada penelitian ini adalah pada objek penelitian yang digunakan, yakni jenis tenun tersebut. 


\section{Metode Penelitian}

Penelitian ini berlokasi di pusat perajin Kain Endek Bali di Sekar Jepun. Lokasi ini dipilih dikarenakan Sekar Jepun tergabung dalam organisasi bagi para perajin Kain Endek Bali dan tenun ikat lainnya untuk Kota Denpasar yaitu Asosiasi Bordir, Endek dan Songket (ASBES). Kain Endek Bali di sini dipusatkan pada Kain Endek Bali area Denpasar yang diproduksi oleh perajin Kain Endek Bali di Sekar Jepun, Denpasar. Data kualitatif dan kuantitatf merupakan jenis data yang digunakan dalam penelitian ini sedangkan data primer dan sekunder merupakan sumber datanya. Teknik pengumpulan data dalam peneitian ini menggunakan teknik observasi, wawancara, angket dan studi dokumen untuk menentukan faktor - faktor internal maupun eksternal sesuai pendapat responden, baik wisatawan maupun masyarakat lokal mengenai pengembangan tenun ikat endek sebagai produk pariwisata kota Denpasar. Teknik sampling yang digunakan dalam menentukan responden adalah accidental sampling. Sedangkan teknik analisis datanya adalah deskriptif kualitatif dan kuantitatif.

\section{Pembahasan}

\section{Potensi Umum Kain Endek}

Perjalanan kain endek memang tidak semulus yang bisa dibayangkan orang. Menurut Rai D. Mantra, walikota Denpasar pada tahun 2007, kain endek Denpasar mengalami keterpurukan (Gatra. 2013). Menurutnya saat itu produksi kain tenun kian menurun tiap tahunnya, terlebih pengerajin yang dimiliki oleh Kota Denpasar hanya 5 orang saja. Hal itu diakibatkan oleh pola pikir masyarakat yang hanya menganggap kain endek hanya dari segi seni dan artistik semata, tanpa bisa diberdayakan sebagai produk lain. Kenyataan tersebut berbeda dengan keadaan kain tenun di tahun-tahun setelahnya. Tercatat oleh Metrobali (2011) pada tahun 2011 saja, terhitung per Januari-Mei tekstil dan produk tekstil (TPT) merupakan 
penyumbang devisa tertinggi Bali, yakni mencapai 59,8 juta dolar AS atau sekitar 27,8\% dari total ekspor non migas Bali. Bahkan sampai di bulan November di tahun yang sama TPT mencatat perolehan devisa mencapai 117,54 juta dolar AS. Tidak hanya sebagai penyumbang devisa negara terbesar di sektor non-migas, TPT juga menyediakan lapangan pekerjaan yang tidak sedikit. Menurut situs web kementerian perindustrian, sektor TPT pada tahun 2013 telah menyerap tenaga kerja sebesar 1,55 juta jiwa dan sekitar 550 ribu lainnya di sektor garmen.

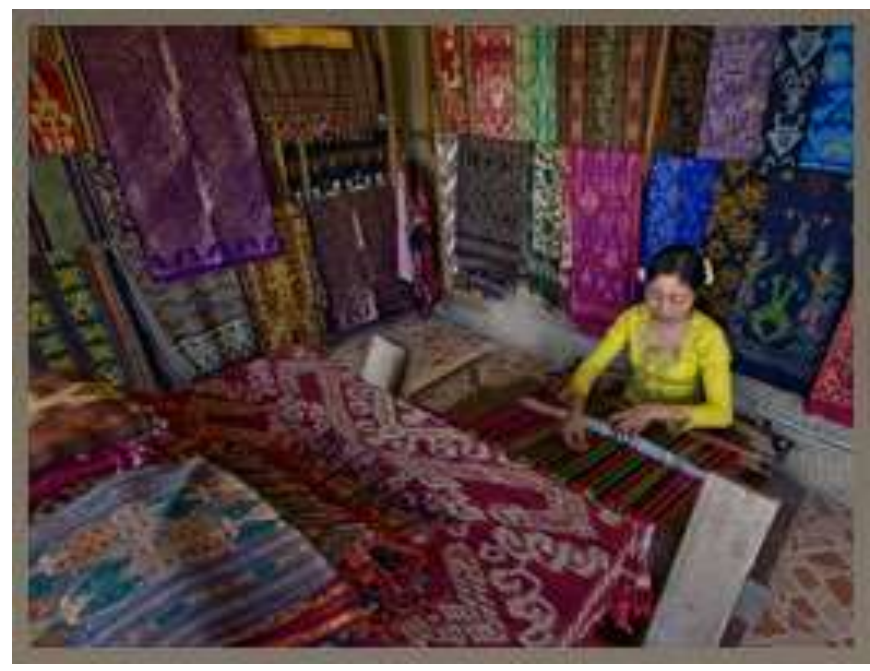

Gamba1. Penenun Endek

Sumber : Lihatsawah.com

Dengan keuntungan yang sedemikian besar, sektor tekstil, termasuk kain endek didalamnya memang menjanjikan potensi yang luar biasa. Jadi tidak salah pemerintah, termasuk pemkot Denpasar berusaha keras menggalakkan potensi endek semaksimal mungkin untuk memberikan kesejahteraan bagi orang banyak. Salah satu cara yang dilakukan adalah dengan melakukan pameran-pameran endek, dan penyelenggaraan Denpasar festival. Menurut Kasubag Pemberitaan Humas dan Protokol Kota Denpasar Dewa Gede Rai di Denpasar (Antara. 2012), pendapatan dari penjualan tekstil dan kerajinan tangan telah menyumbang sebesar Rp1,1 miliar diraih dari total penjualan $\mathrm{Rp}$ 3,1 miliar yang diperoleh pada penyelenggaraan Denpasar Festival pada tahun 2011 silam. Sebuah potensi yang cukup besar yang JUMPA Volume 05, Nomor 02, Januari 2019 
dimiliki oleh kain tenun Denpasar. Disamping itu pemkot juga berusaha untuk mengembalikan kejayaan pasar kumbasari dengan Imperium Kumbasari, mengingat pasar Kumbasari pernah sangat jaya dalam pemasaran kain endek pada era tahun 1980-an, meski sekarang sentra itu sudah bergeser ke daerah lain.

Selain itu potensi yang dimiliki oleh kain endek Denpasar adalah kain endek ini disukai oleh wisatawan asing. Terlihat dari banyaknya pengerajin kain endek Denpasar yang telah mengekpor kain ini ke negeri Sakura, Jepang (Antara. 2012). Dikatakan masyarakat Jepang menyukai kain endek ini karena kain endek Denpasar memiliki kualitas dan desain yang baik.

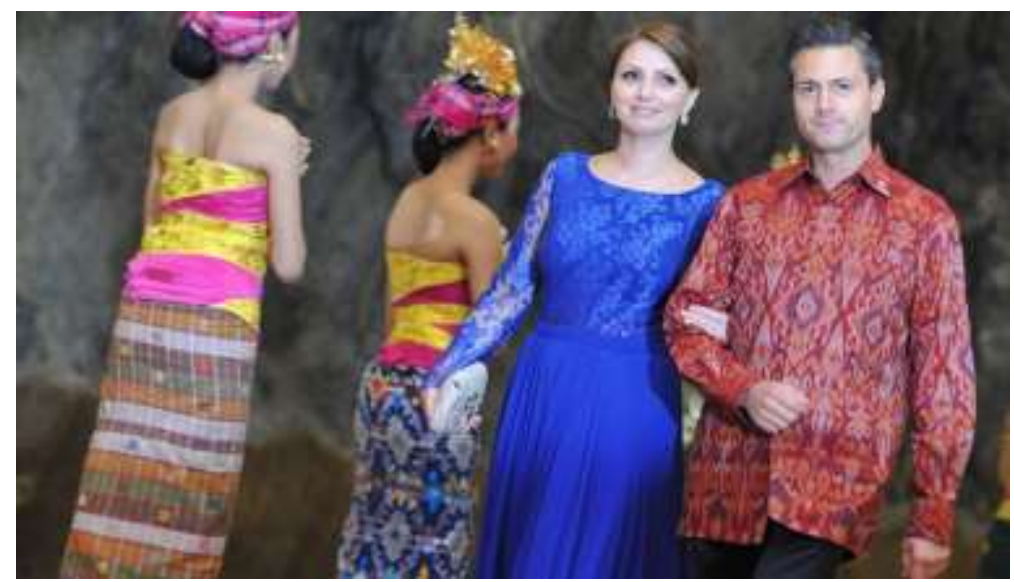

Gambar 2. Presiden Meksiko Enrique Pena Nieto (kanan) Menggunakan Endek Sumber : Tempo (2017)

Potensi lain yang dimiliki oleh kain endek ini adalah dibidang penggunaannya. Memang disadari kalau kain endek pada masa terdahulu hanya dipakai oleh kaum bangsawan dan orang tua serta dekat dengan lingkungan puri. Namun saat produksi kain endek sudah mulai masal dan dengan harga yang terjangkau, membawa efek positif terhadap pertumbuhan kreatifitas para desainer pakaian. Tidak hanya itu, kain endek juga menjadi busana harian masyarakat modern saat ini. Padu padan kain endek sudah mulai dilakukan, tidak hanya menganut pakem kalau endek hanya sebatas kain untuk bawahan saja, namun bisa 
dimodifikasi menjadi atasan, misalnya baju ataupun dasi. Disana terlihat kalau kain endek ini menjadi biasa, bahkan bagi anak-anak muda Bali.

\section{Potensi Komodifikasi Kain Endek sebagai Produk Industri Pariwisata Kreatif}

\section{Faktor Internal}

Untuk mengembangkan potensi kain endek Denpasar sebagai bagian dari produk pariwisata, tidak terlepas dari dukungan daerah sekitar serta daerah penyangganya. Daerah yang dimaksud tentu saja kota Denpasar sendiri serta daerah penyengga seperti Kabupaten Badung dan Kabupaten Gianyar. Hal ini penting adanya untuk membantu keberadaan kain endek Denpasar untuk menjadi salah satu ikon penting sebagai produk pariwisata yang dapat secara luas diterima dan dibanggakan. Untuk mencapai hal tersebut maka dalam analisis faktor internal potensi pengembangan kain endek Denpasar sebagai produk pariwisata, maka perlu dilakukan analisis terhadap 4 variabel utama yaitu a) Daya Tarik (Attraction), b) Aksesibilitas (Accessibility), c) Fasilitas/Kenyamanan (Amenities), d) Jasa Pendukung (Ancillary Service) (Cooper et al. 2000. Dalam Wahdiat. 2011). Penjelasan lebih lengkap dapat dilihat dibawah ini:

a. Daya Tarik (Attraction)

Kain endek Denpasar, dalam penelitian ini, dapat dikategorikan sebagai daya tarik hasil cipta manusia kategori sosial budaya. Keberadaannya sudah ada di daerah ini selama beratus tahun lamanya dan telah melalui proses yang cukup panjang. Untuk analisa faktor internal dalam hal daya tarik ini, beberapa indikator sudah disiapkan untuk mempermudah penilaian dan melihat umpan balik dari para responden.

Indikator pertama adalah motif kain. Menurut 12 dari 26 responden, atau sebesar $46,1 \%$ responden menyatakan bahwa motif dari kain endek Denpasar yang unik merupakan factor yang menarik responden untuk membeli kain endek Denpasar. Motif dasar kain endek Denpasar memiliki ciri khas tersendiri yang 
membedakannya dengan kain endek dari daerah lain. Kain endek Denpasar memiliki motif flora atau bunga yang indah. Motif ini terus dipertahankan ditengah kemajuan jaman dan banyaknya bermunculan motif lainnya. Hal ini tentu saja menjadi daya tarik tersendiri bagi banyak wisatawan yang ingin memiliki kain endek Denpasar ini.

Selain motif, warna yang dimiliki oleh endek Denpasar juga sangat menarik. Sebanyak 8 responden atau sebesar 30,7\% menyatakan bahwa warna yang dimiliki oleh kain endek Denpasar merupakan indikator yang menyebabkan mereka untuk ingin memiliki kain endek Denpasar. Keindahan warna dari kain endek Denpasar dikarenakan oleh penggunaan metode pewarnaan alami yang menghasilkan warna yang tidak seterang kain endek yang melalui proses pewarnaan buatan. Akan tetapi dengan teknik pewarnaan alami, warna dari kain endek tersebut tidak akan luntur, sebaliknya dengan semakin sering dicuci warna dari kain tersebut akan semakin bagus. Hal ini menjadi keunikan tersendiri dari kain endek Denpasar.

Sebagai akibat dari proses pewarnaan alami yang menghabiskan waktu lebih panjang dan biaya yang lebih besar dari proses pewarnaan buatan produksi kain endek Denpasar menjadi terbatas. Hal ini yang menjadikan harga sebagai indikator ketiga dari factor internal pengembangan kain endek Denpasar. Sebanyak 6 responden atau sebesar 23,1\% responden menyatakan harga sebagai pertimbangannya untuk membeli kain endek Denpasar. Indicator harga menimbulkan sisi positif dan negative. Sisi positif dari terbatasnya jumlah produksi kain endek Denpasar adalah kain endek ini menjadi rebutan bagi para kolektor kain dan para penggemar endek untuk dijadikan koleksi serta investasi yang cukup menjanjikan karena akan berharga sangat mahal di kemudian hari. Disamping itu pemakai juga memiliki harapan untuk dapat meningkatkan prestise saat memakai kain ini sehingga rasa bangga kalau berhasil mengkoleksi kain tenun asli dari daerahnya. Sisi negatifnya adalah, dengan keterbatasan produksi kain endek ini 
membuat harga kain endek Denpasar menjadi terbilang cukup mahal dipasaran sehingga tidak semua orang mampu membeli kain endek ini.

Ditambahkan oleh para responden juga, bahwa akan sangat disayangkan kalau sampai produksi kain endek Denpasar ini bersifat masal. Selain dikhawatirkan akan menurunkan kualitas kain, tentu kesan eksklusif yang selama ini dimiliki menjadi tidak begitu penting lagi. Memang perlu juga disadari ada beberapa jenis kain endek Denpasar yang diproduksi secara masal dengan menggunakan benang yang lebih murah dan pewarna buatan. Namun tetap saja kualitas kain yang diproses secara alami tetap diminati dan diburu oleh para peminatnya.

Indikator keempat atau terakhir adalah potensi kain endek Denpasar untuk dirubah bentuk, fungsi maupun kegunaannya atau yang biasa disebut dengan komodifikasi. Hal ini sangat sering dan mudah dijumpai belakangan ini untuk menambah daya jual kain ini. Menurut pengerajin dan produsen, kain endek Denpasar sangat mudah dirubah menjadi banyak model, seperti pakaian, ikat kepala, dan lainnya. Selain bentuk dan warna yang pas, satu lembar kain endek Denpasar juga dapat dirubah menjadi banyak model. Ini tentu saja berhubungan dengan keuntungan yang dapat diperoleh oleh pengerajin atau produsen yang melakukan komodifikasi ini.

\section{b. Aksesibilitas (Accessibility)}

Aksesibilitas merupakan faktor lainnya yang tidak kalah penting dalam pengembangan kain endek Denpasar. Tanpa adanya akses, maka daya tarik wisata tersebut tidak akan terjangkau oleh para wisatawan. Seperti yang diketahui, kota Denpasar merupakan pusat pemerintahan Provinsi Bali, hal tersebut menjadikan akses jalan di kota Denpasar bisa dikategorikan sangat bagus. Bahkan belakangan pelabuhan Benoa telah sedikit demi sedikit akan menuju pelabuhan yang melayani arus pariwisata seperti sebagai akses pelabuhan Kapal Pesiar, sehingga banyak wisatawan mancanegara yang berkunjung ke Denpasar melewati pelabuhan ini. Dilihat dari infrastrukturnya, pelabuhan Benoa memiliki fasilitas yang baik dan 
bagus sehingga mampu berfungsi dengan baik untuk mendukung pariwisata. Baiknya insfratruktur dari Kota Denpasar maupun daerah-daerah penyangga menyebabkan mudahnya wisatawan untuk mengakses Kota Denpasar, sehingga kemungkinan para wisatawan untuk melihat dan membeli kain endek Denpasar juga semakin besar.

Namun yang menjadi perhatian responden adalah beberapa kemacetan yang terjadi di beberapa ruas jalan di kota Denpasar, terutama pada jam-jam tertentu. Semisal di daerah Imam Bonjol yang berdekatan dengan daerah wisata Seminyak dan Kuta yang sering mengalami kemacetan di pagi hari, sekitar pukul 8.00 dan di sore hari sekitar pukul 16.00. Pada jam-jam tersebut tergolong -jam sibuk saat orangorang sedang berangkat ke tempat kerja dan pulang ke tempat kerja. Disaat seperti itu juga banyak wisatawan yang mengeluhkan kemacetan yang terjadi sehingga mengganggu kenyamanan mereka saat berlibur di kota Denpasar. Hal ini juga yang menyebabkan mereka sulit untuk mencapai sentra- sentra kain endek Denpasar.

Sebanyak 21 responden atau sebesar 80,7\% responden menyatakan bahwa sulitnya mereka mencapai sentra-sentra kain endek Denpasar disebabkan oleh kemacetan yang terjadi di Denpasar. Sedangkan 5 responden atau sebesar 19,3\% tidak memberikan pendapatnya dalam hal ini. Kemacetan yang terjadi di ruas- ruas jalan Denpasar menyebabkan para wisatawan kelelahan sehingga akan sedikit menurunkan niat mereka untuk mengunjungi sentra- sentra kain endek Denpasar. Adapun kualitas dari infrastrukur atau kualitas dari jalan itu sendiri sangat baik dan tidak ada kendala.

Untuk mengatasi masalah kemacetan tersebut pemerintah Denpasar telah melakukan sebuah program terintegrasi dengan daerah penyangga dengan, salah satunya, adalah program transportasi yang disebut Trans Serbagita, yang merupakan akronim dari jalur yang dilalui oleh transportasi umum ini, DenpasarBadung-Gianyar-Tabanan. Untuk menambah kenyamanan, terdapat juga jalur-jalur 
kecil yang dilalui kendaraan shuttle bus yang melintasi daerah dalam kota Denpasar sehingga para penumpang bisa sekalian berkendara dengan nyaman dan murah. Namun ternyata keberadaan Trans Serbagita ini masih kurang populer, dimana warga masih banyak menggunakan transportasi pribadi sehingga kemacetan memang susah untuk dihindari. Jadi masalah ini masih merupakan PR bagi pemkot Denpasar. Meski begitu wisatawan juga dapat memilih moda transportasi lainnya seperti yang ditawarkan travel agent dan atau menyewa sepeda motor dan mobil yang banyak disewakan di kota Denpasar.

c. Kenyamanan (Amenities)

Faktor kenyamanan yang dimaksud adalah fasilitas pendukung kenyamanan para wisatawan yang mengunjungi kota Denpasar. Adapun beberapa contoh fasilitas tersebut adalah hotel, restoran, bar, pusat perbelanjaan, money changer, dan pusat oleh-oleh baik modern ataupun tradisional. Keberadaan fasilitas-fasilitas pendukung tersebut sudah banyak tersebar di penjuru kota Denpasar. Banyak hotel mulai dari hotel melati samapi dengan hotel berbintang lima tersebar di Denpasar, begitu juga dengan restoran dan bar. Beragam jenis makanan telah tersedia, mulai dari makanan tradisional sampai dengan makanan yang berasal dari berbagai belahan dunia telah tersedia. Pusat perbelanjaan sangat mudah dijumpai di Denpasar, sama hal nya dengan pusat oleh- oleh. Pusat oleh- oleh yang menyediakan oleh-oleh khas Denpasar ataupun Bali dapat ditemui di titik- titik penting di Kota Denpasar. Sedangkan amenities atau faktor kenyamanan yang mendukung pengembangan kain endek Denpasar itu sendiri selain yang penulis sebutkan tersebut adalah tempat parkir, toilet, dan kebersihan dari sentra- sentra kain endek yang ada di Denpasar.

Seluruh responden menyatakan puas akan fasilitas toilet serta kebersihan dari sentra- sentra endek Denpasar. Yang menjadi keluhan dari 20 responden atau sebesar $76,9 \%$ responden adalah ketersediaan tempat parkir dari sentra- sentra endek tersebut. Kapasitas dari tempat parkir yang disediakan oleh sentra endek 
Denpasar hanya mampu menampung empat samai lima mobil keluarga atau hanya mampu menampung dua buah mini bus. Sedangkan bus berukuran sedang tidak memperoleh parkir, sehingga harus diparkir agak jauh dari sentra endek. Hal ini menyebabkan para wisatawan harus berjalan jauh dan mengurangi kenyamanannya.

\section{d. Jasa Pendukung (Ancillary Service)}

Ancillaries atau jasa pendukung sangat terkait dengan tersedianya badan, organisasi, atau orang-orang yang mengurus sebuah destinasi. Jasa pendukung ini menjadi penting disebabkan karena walaupun sebuah destinasi telah memiliki atraksi, aksesibilitas, dan amenitis yang baik, tetapi jika tidak ada uang mengatur dan mengurus destinasi tersebut, maka untuk kedepannya destinasi tersebut tidak akan dapat berlangsung lama. Adanya sebuah badan, organisasi, atau orang-orang yang mengatur sebuah destinasi memiliki peranan seperti sebuah perusahaan. Ancillaries ini yang akan mengatur dan mengurus sebuah destinasi sehingga destinasi tersebut dapat memberikan keuntungan bagi pihak terkait, seperti masyarakat sekitar, pemerintah, wisatawan, lingkungan, dan para stakeholder lainnya.

Sebanyak 23 responden atau sebesar $88,5 \%$ responden menyatakan bahawa ancillaries untuk kain endek Denpasar sudah sangat membantu dalam memberikan penjelasan akan kain endek Denpasar itu sendiri. Promosi juga dilakukan oleh Pemerintah Kota Denpasar sudah sangat baik. Keberadaan kain endek Denpasar sudah banyak dikenal oleh dunia. Beberapa pergelaran dan pameran juga sudah dilakukan, seperti Denpasar Festival yang rutin dilakukan setiap tahunnya. Pengelolaan setiap daya tarik juga mendapatkan respon yang baik oleh para wisatawan. Berbagai papan informasi telah tersedia diberbagai sudut yang juga mempermudah para wisatawan untuk mengenal atau mendapatkan informasi yang tepat tentang sebuah objek wisata. Begitu juga informasi yang tersedia di website 
resmi pemkot Denpasar juga sangat membantu para wisatawan dalam menemukan tempat yang tepat untuk mereka kunjungi.

\section{Faktor Eksternal}

Variabel-variabel yang dianalisis pada faktor eksternal berkontribusi terhadap pengembangan kain endek Denpasar sebagai produk pariwisata diantaranya bidang politik, ekonomi, sosial budaya, informasi teknologi, lingkungan, keamanan, serta daya saing. Diantara variabel tersebut yang mendapat poin tertinggi atau yang paling dirasa berpengaruh oleh para responden adalah variable informasi dan teknologi. 24 reponden atau sebesar 92,3\% responden menyatakan bahwa teknologi dan informasi merupakan faktor yang sangat penting untuk mengembangkan kain endek Denpasar menjadi produk wisata Denpasar khususnya, dan Bali pada umumnya. Dijaman yang serba digital dimana seluruh dunia saling terhubung satu sama lainnya, keberadaan informasi dan teknologi akan sangat penting karena bisa mempengaruhi segala bidang. Diantaranya adalah faktor promosi. Dengan adanya internet, promosi bisa dilakukan dengan sangat spontan dan efisien. Dengan keberadaan, salah satunya, media sosial yang semakin menjamur belakangan ini, maka promosi bisa dilakukan dari tempat duduk dan menjangkau seluruh dunia secara viral. Untuk memperkenalkan keberadaan kain endek Denpasar dengan cara "kuno" seperti iklan di Koran, televisi, atau papan reklame, akan sangat makan waktu dan biaya yang tinggi. Dengan jejaring sosial, seseorang yang hidup di sisi lain dunia bisa melihat keberadaan kain endek Denpasar dalam waktu singkat, sekaligus melihat bagaimana potensi dan perkembangan kain kebanggaan Denpasar ini dengan lebih rinci. Selama ini Pemkot Denpasar sudah sangat baik memanfaatkan keberadaan informasi dan teknologi ini, sehingga kain endek Denpasar bisa lebih dikenal dunia.

Dibidang sosial budaya, seperti daerah lainnya di Pulau Bali, kota Denpasar juga sangat menjungjung tradisi dan kehidupan sosial budayanya. Dibanyak sudut kota dapat dilihat berbagai komunitas yang tergabung dalam sebuah banjar 
(populasi yang lebih kecil dari desa, semacam dusun), para warga kerap melakukan kegiatan keagamaan dengan menggunakan kain endek. Disini terlihat kalau penggunaan kain endek tidak hanya sebatas paduan busana untuk kegiatan resmi yang ada selama ini, namun juga terlihat hampir di keseharian mereka. Hanya saja kalau melihat ciri kota yang sudah dipengaruhi kehidupan modern yang mengutamakan persaingan setiap individu serta gempuran efek pariwisata, maka sedikit tidaknya pola pikir masyarakatnya juga mengarah ke pola piker yang individualis. Hal ini juga berpengaruh kepada kenyamanan para wisatawan yang kebetulan sedang berkunjung ke kota Denpasar, dimana sebagai contoh saat bertanya tentang tempat atau sebuah informasi, maka respon yang didapat dari warga Denpasar tidak akan "seramah" yang biasa didapatkan dari penduduk yang tinggal di pedesaan.

Dibidang ekonomi, pengaruh ekonomi dunia juga tidak bisa dianggap remeh. Menurut responden yang menjadi pengerajin di kota Denpasar, permintaan akan kain endek Denpasar menjadi berkurang saat terjadi krisis ekonomi yang pernah terjadi di Indonesia. Dan sekarang saat dimana keadaan ekonomi dunia sudah semakin membaik, begitu juga yang terjadi dengan permintaan terhadap kain endek Denpasar. Pesanan mulai meningkat tajam yang berdatangan dari berbagai penjuru. Selain itu faktor keamanan dan politik suatu daerah juga menjadi perhatian para wisatawan saat berkunjung ke sebuah daerah. Menurut cerita responden yang menjadi pengrajin kain endek Denpasar, dahulu saat terjadi bom Bali, kunjungan wisatawan sangat menurun drastis yang juga berpengaruh terhadap menurunnya omset penjualan kain endek Denpasar. Namun berbeda dengan keadaan Bali yang kelam pada masa itu, saat ini keamanan dan situasi politik Bali dianggap biasa saja dan kondusif oleh para wisatawan, sehingga telah banyak yang mengunjungi Bali, dan kota Denpasar secara khusus. 
Faktor terakhir yang juga menjadi faktor perhatian adalah faktor daya saing dari kain endek Denpasar ini sendiri. Harus sangat disadari kalau kain endek Denpasar memang cukup kalah terkenal dengan kain tradisional jenis lain, katakanlah kain Batik atau Kain Songket yang sudah sangat mendunia. Disamping itu kain endek Denpasar selama ini memang tidak memiliki sentra yang cukup terkenal sebagai pusat penjualan khusus kain Endek Denpasar. Maka dari itu pemkot sedang berusaha menghidupkan pasar Kumbasari, terutama di area lantai 4, sebagai sentra pameran dan penjualan kain endek Denpasar, dimana lokasi tersebut dulunya pernah terkenal sebagai pusat penjualan kain endek Denpasar. Selama ini para wisatawan selalu mengarah ke sentra penjualan lainnya di luar Denpasar, seperti pasar seni Sukawati, berbagai pasar oleh-oleh Bali yang dimiliki oleh pihak swasta, atau ke pasar Ubud.

Untuk memperkecil daya saing ini, pemkot Denpasar juga telah melakukan berbagai hal yang menyangkut promosi, diantaranya yang telah dilakukan nyonya Rai D. Mantra (istri walikota Denpasar), yang telah mengenakan kain endek Denpasar ke setiap kunjungan serta acara resmi pemerintah kota, agar sekaligus memperkenalkan kain edek Denpasar kepada dunia luar. Nyonya Rai Mantra telah sekaligus, secara tidak resmi, dianggap sebagai duta endek Denpasar. Promosi lainnya yang sudah dilakukan adalah dengan melakukan berbagai pameran kain endek dan turunannya di luar negeri. Hal ini juga sangat positif dilakukan untuk memperkenalkan kain endek ini ke segmen pasar internasional. Untuk memperbaiki ketimpangan daya saing ini juga, para desainer dan pengrajin endek juga sudah mulai berinovasi dalam mengolah kain endek sehingga tidak hanya dipakai sebagai kamben saja, tetapi juga diolah menjadi baju, celana, rompi, ikat kepala, bahkan sampai menjadi sepatu atau asesoris lainnya. 


\section{Simpulan dan Saran}

Potensi Komodifikasi Tenun Ikat Endek Bali sebagai produk industri pariwisata kreatif sangat fisibel dalam pengembangannya. Hal ini dikarenakan Kain Tenun Ikat Endek Bali memiliki 1) motif dasar dengan ciri khas tersendiri seperti motif flora atau bunga yang indah, 2) warna sangat menarik dengan pewarnaan alami, 3) harganya sangat bervaritif, dan 4) modifikasi dengan berbagai macam model. Dengan didukung adanyanya akses yang sangat baik seperti; jalan, transportasi, pelabuhan dan bandara tersedi dengan lengkap. Ketersediaan amenitas yang baik berupa hotel, restoran, bar, pusat perbelanjaan, money changer dan pusat oleh-oleh. Ancillary Service pada kawaan sangat mendukung dengan adanya keterlibatan secara langsung oleh pemerintah Kota Denpasar. Selain itu juga, media promosi dalam pemanfaatan keberadaan informasi dan teknologi pun sangat mendukung. Social budaya pun sangat menjungjung nilai tradisi dan kehidupan social budayanya. Dan keadaan ekonomi dunia semakin membaik yang mempengaruhi peningkatan permintaan terhadap kain endek walaupun tingkat persaingan sangat tinggi. Namun potensi perkembangan tenun ikat endek sampai saat ini sangat meningkat pertumbuhannya. Yang didukung dengan adanya kegiatan tahunan seperti festival Denpasar. Potensi lain yang dimiliki Kain Endek ini adalah 1) salah satu penyumbang devisa Negara, 2) isukai oleh wisatwan asing, dan 3) dapat dimanfaatkan berbagai bentuk desain menarik seperti; pakaian, dasi, tas, maupun dompet.

Sesuai dengan pembahasan di atas mengenai Endek sebagai produk kreatifitas local yang tidak dapat dipisahkan dari dukungan pemerintah pusat dan pemerintah daerah. Adapun kebijakan yang dapat diambil untuk menyokong pengembangan potensi kain Endek adalah sebagai berikut: 


\section{Pemerintah Daerah}

a. Dalam rangka menjaga kelestarian endek, pemerintah kota Denpasar dapat mengadakan pelatihan menenun dan kegiatan terkait bagi warga kota.

b. Membuatkan lembaga berbasis kemasyakaratan untuk menjadikan wadah penjualan serta memberikan dukungan berupa modal bagi pengusaha kain endek.

c. Menambah jumlah usahawan dalam bidang tenun endek dengan mempermudah ijin pendirian dari kegiatan usaha.

d. Menggiatkan hari tertentu sebagai hari berpakaian endek di dinas pemerintahan

e. Membawa endek sebagai salah satu kekayaan budaya Bali yang ditunjukkan pada pameran budaya yang rutin dilakukan oleh Pemda daerah lain.

f. Memberikan lokakarya mengenai kebersihan lingkungan kepada masyarakat dalam rangka melestarikan lingkungan dan menjaga kenyamanan bersama.

\section{Pemerintah Pusat}

a. Membawa endek Denpasar sebagai kekayaan budaya Indonesia di event-event bertaraf internasional

b. Mendorong penggunaan endek ke kancah peragaan busana kelas dunia dengan mengundang para desainer Indonesia dan dunia.

\section{Daftar Pustaka}

Barker, C. 2004. Cultural Studies: Teori \& Praktik, (Terjemahan Nurhadi). Yogyakarta: Kreasi Wacana.

Baudrillard, J. 2009. Masyarakat Konsumsi (La Societe de Consommation). (Terjemahan). Yogya- karta: Kreasi Wacana.

Bourdieu, 2010. Arena Produksi Kultural (The Field of Cultural Production): Sebuah Kajian Sosi- ologi Budaya (Essays on Art and Literature). (Terjemahan). Yogyakarta: Kreasi Wacana. 
Foucault, M. 2007. Order of Thing Arkeologi ilmu-Ilmu Kemanusiaan (The Order of Things An Archaeology of Human Sciences). Yogyakarta: Pustaka Pelajar.

Prasidha, P. L., 2012. "Batik Sebagai Sejarah Warisan Budaya Di Jawa Tengah (Studi Kasus: Kampung Batik Kauman-Solo)". (tesis). Denpasar: Universitas Udayana.

Piliang, Y.A. 1998. Sebuah Dunia yang Dilipat, Realitas Kebudayaan Menjelang Malenium Ketiga dan Matinya Posmodernisme. Yogyakarta: Jalasut

Picard M.. 2006. Bali Pariwisata Budaya dan Budaya Pariwisata. Jakarta: KPG Kepustakaan Populer Gramedia.

Polanyi, K.. 2003. Tranformasi Besar: Asal-Usul Politik dan Ekonomi Zaman Sekarang (The Greet Transformation: The Political and Social Origins of Our Time). (terjemahan). Yogyakarta: Pustaka Pelajar.

Prakosa, S., Cheon, H. 2013. “Thai tourists' souvenir shopping experience in Korea”. Asia Marketing Journal 15(3), 15-29. ISSN: 1598-7868.

Nugraha, I.G.P., 2012. "Implementasi Sightseeing Denpasar Sebagai Program Promosi Pariwisata Kota Denpasar". (tesis). Denpasar: Universitas Udayana.

Titib, I.M.. 2003. Teologi \& Simbol-Simbol dalam Agama Hindu. Surabaya: Paramita.

\section{Profil Penulis}

I Gusti Ayu Melistyari Dewi dilahirkan di Karangasem, Bali 16 Maret 1988. Menyelesaikan pendidikan DIV Perhotelan pada tahun 2010. Saat ini aktif sebagai instruktur pelatihan kantor depan dan tata graha di salah satu lembaga pelatihan yang ada di denpasar. I Gusti Ayu Melistyari Dewi juga terdaftar menjadi salah assesor kompetensi bidang pariwisata dan perhotelan. E-mail: melistyari.dewi@gmail.com

I Wayan Ardika dilahirkan di Tabanan, Bali 18 Februari 1952, merupakan salah satu Guru Besar bidang arkeologi pada Fakultas Sastra. Prof. Dr. I Wayan Ardika, M. A. menduduki jabatan Dekan Fakultas Pariwisata (1999-2001), kemudian menjabat sebagai Dekan Fakultas Sastra Unud (dalam dua kali jabatan 2003-2011). Lulusan 
Sarjana Arkeologi Universitas Udayana (1979), Master Prehistory, Canberra, Australia National University (1987), dan Doktor Prehistory di tempat yang sama tahun (1992). Kelompok Ahli Pembangunan Provinsi Bali Bidang Sosial Budaya (2000-2009). E-mail: ardika52@yahoo.co.id

I Nyoman Sunarta menjabat sebagai Dekan Fakultas Pariwisata Unud (2017-2021). Beliau menyelesaikan pendidikan S1 di Fakultas Geografi UGM (1986), S2 di Ilmu Lingkungan, Fakultas Geografi UGM (1994), dan pendidikan S3 di Kajian Pariwisata Unud (2015). Beliau juga pernah menjadi sekretaris PPLH Unud 1998-2002. Pada saat sama ditugaskan sebagai anggota Tim ahli pembangunan Bali dan Kota Denpasar. Beberapa tulisannya dimuat di berbagai jurnal nasional dan internasional. Ia juga aktif berbicara dan mempresentasikan pemikirannya dalam berbagai konferensi di dalam dan luar negeri. Pernah mengelola program Dikti Double Degree Indonesia Perancis S2 dan S3 bidang pariwisata di Pascasarjana Unud. Email: cairns54@yahoo.com 